\title{
The Properties of Protease Isolated from Tissues of Benign and Malignant Kidney Tumors Patients
}

\author{
Lelas F. Bdaiwi \\ Department of Chemistry \\ College of Science \\ University of Mosul \\ E-mail: laelasfarhan@yahoo.com
}

(Received $10 / 5$ / 2012 ; Accepted $10 / 9$ / 2012)

\begin{abstract}
The research includes the study of some protease properties in seven patients diagnosed with kidney tumors. Three of them were benign and the others were malignant.

The samples were collected from the patients directly after undergoing the surgery in Al-Jamhoory hospital in Nineveh Governorate, Iraq.

Protease enzyme was isolated using different biochemical techniques, like ammonium sulphate precipitation, dialysis and gel filtration chromatography on sephadex G-100. The comparative molecular weight of protease was determined using gel filtration and was found to be (72000 and $75000 \pm 2000)$ dalton for benign and malignant tumors respectively.

The results showed that there was a (55\%) increase in the specific activity of protease in malignant kidney tumors than benign.

The optimum conditions for protease activity were obtained using sodium borate buffer at $\mathrm{pH}(8.8)$ for (1) minute incubation at $\left(40^{\circ} \mathrm{C}\right)$ and $(0.4) \mathrm{mM}$ of casein as a substrate $\mathrm{V}_{\max }$ and $\mathrm{K}_{\mathrm{m}}$ were found to be $(0.87 \mathrm{U} / \mathrm{ml})$ and $(0.22 \mathrm{mM})$ respectively by Linweaver-Burk plot.

Finally, the effect of some chemical compounds like iodoacetamide, mercurous chloride, zinc sulphate showed an inhibition impact on protease activity while calcium sulphate and magnesium chloride demonstrated an increase effect on the protease activity.
\end{abstract}

Keywords: Kidney cancer, protease, properties.

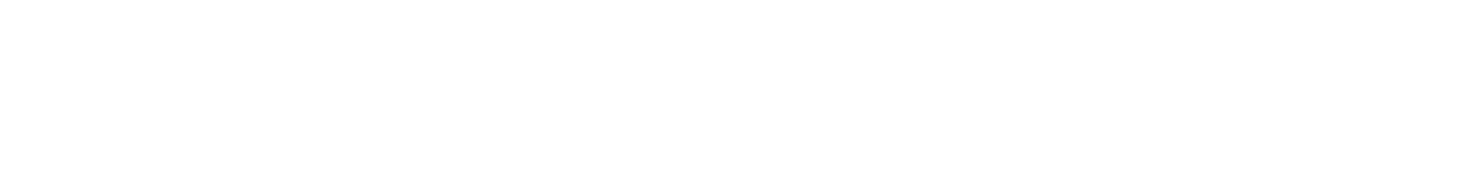

تضضن البحث درلسة فعالية إذزيم البروتيز للأشخاص مصابين بأورلم الكلى الحمية والخبيثة وقد ك لن عدد العينات المدروسةسبعة، ثلاثة منها مصابين بأورله حمية والبقية خبيثة. مُ جمع العينت من وحة الجرلحة في المستثفى الجمهوري في محلظة نينوى، العرق، وت م ع ـزل

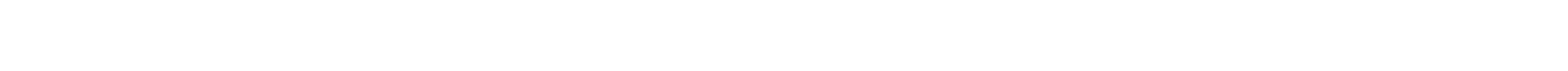
التسيب بكبريتك الأمونيوم والديلزة وققنية التشبح الهلامي بلستخده للسفكس (G-100)، ثم قدر ال ـوزن 
الجزيئي للإذزيم وكان بمدى (72000 و 75000 ـ 2000) دالتون للورم الحميد والخبيث على الت ـوالي.

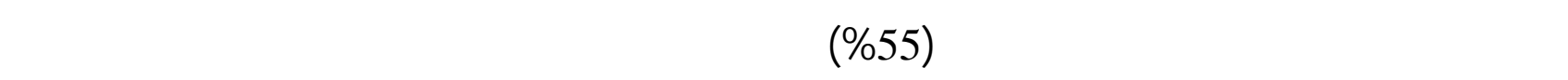

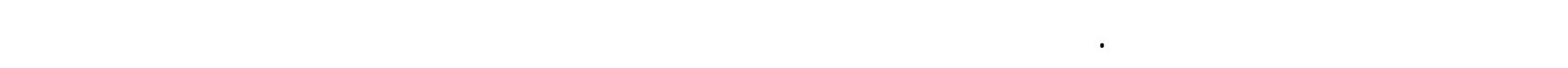

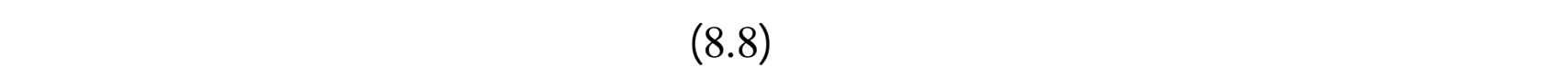

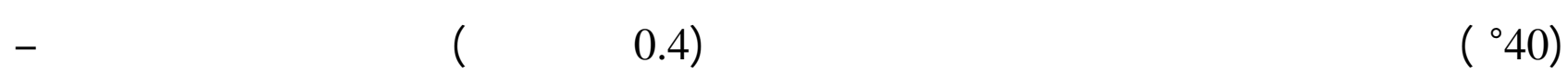

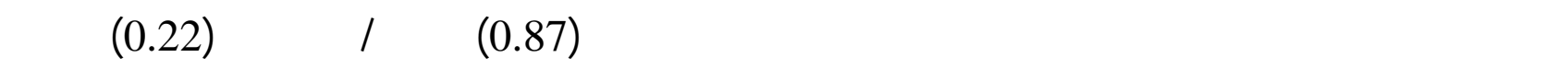
مول على التوالي. وأخيراً تمت درلسة تأثير بعض المواد الكيميائية على فعالية الإذزيم مل لأسيتلميد الصوديوم وكلوري ـ2

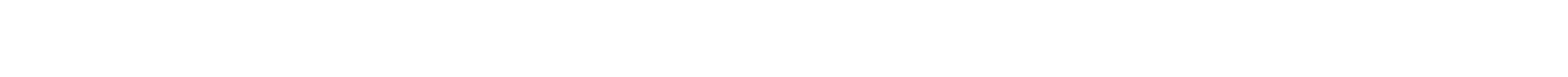
كلوريد المغنيسيوم فقد لُٔهرتا تأثيرَ تتشيطياً. الكاملت الدالة: البروتيز،سرطان الكلى، صفل.

\section{INTRODUCTION}

Kidney cancer is also called hypernephroma or renal cancer and defined as cancer that is formed in the tissues of the kidneys and it is found in three kinds:

1- Renal cell carcinoma:- cancer that forms in the lining of very small tubes in the kidney that filters the blood and remove waste products.

2- Renal pelvis carcinoma:- cancer that forms in the center of the kidney where urine collects.

3- Wilms tumor:- which is a type of kidney cancer that is usually developed in children under the age of 5 years (National cancer Institute, 2012).

Protease (also termed peptidase or proteinase) is an enzyme conducts proteolysis which begins protein catabolism by the hydrolysis of the peptide bonds that link amino acids together in the poly peptide chain forming the protein (Rawlings et al., 2010). It is an essential constituent of all forms of life on earth including prokaryotes, fungi, plants and animals (Gupta et al., 2002). This enzyme is involved in a multitude of physiological reactions from simple digestion of food proteins to highly regulated cascadase like blood clotting (Sims, 2006).

Protease is highly explotid enzyme in food leather, detergent, pharmaceutical diagnostics waste management and silver recovery (Gupta et al., 2002). It constitutes 50$65 \%$ of the global industrial enzyme market (Sankaralingam et al., 2011). Protease is essential for many physiological processes. Thus their dysregulation has been implicated in a variety of disease processes such as infection diseases, cardiovascular, cancer and other diseases. (Hooper, 2002).

The aim of this research was to:

(1) Isolate and Purify the protease from benign and malignant kidney tumors and to determine its activity in these tissues. 
(2) Determine the protease optimal conditions and study the effect of some chemical compounds on its activity.

\section{MATERIALS AND METHODS}

\section{Patients:}

Patients in this study were enrolled to the surgery unit in Al-Jamhoory hospital in Nineveh governorate, Iraq.

Samples of (7) patients diagnosed clinically as having kidney tumor and they were males depending on the histopathological examination, (4) patients were diagnosed as having malignant kidney tumors while (3) patients were diagnosed as benign kidney tumors.

\section{Samples:}

A- Kidney tissue samples were collected immediately after operation. The tissues were cut off, rinsed with normal saline and kept frozen at $\left(-20^{\circ} \mathrm{C}\right)$ until analyzed.

B- Tissue homogenate preparation.

The samples from section - A, having the size of $(1 \times 1)-(1 \times 2)$, cm were cut into small pieces in a petri dish. The slices were homogenized by hand homogenizer in an ice bath using sodium borate buffer $(0.1 \mathrm{M} \mathrm{pH} 8.4)$ in a ratio of $(1: 10 \mathrm{w} / \mathrm{v})$. Then the homogenated mixture was sonicated for four cycles of (15) seconds with (15) seconds interval in between, then filtered through double layer of sterile gauze and centrifuged at (6000 xg) for (15) minutes in a cooling centrifuge. The supernatant was separated and divided in aliquot and kept frozen at (-20) for protein and enzyme activity measurement (Price and Stevens, 1989).

\section{Enzyme assay:}

The enzyme activity was determined using the literature method (Worthington, 2012).

\section{Protein estimation:}

The method used for protein determination was modified Lowery method (Schacterle and Pollack, 1973) where bovine serum albumin(BSA) was used as a standard.

\section{Isolation and purification of the enzyme from kidney tissues:}

The enzyme was purified from the kidney tissues according to the following:

\section{1- Protein precipitation by ammonium sulphate:}

Total protein from tissues extract was precipitated using (75\%) ammonium sulphate solution (Robyt and White, 1987).

The precipitate was separated by cold centrifugation at (10000 xg) for (15) minutes. The protein concentration was estimated and the protease activity was measured.

\section{2- Dialysis:}

The precipitate was dissolved in distilled water and dialyzed against $0.1 \mathrm{M}$ ammonium bicarbonate solution. The solution was stirred with a magnetic stirrer over night at $4^{\circ} \mathrm{C}$ and the buffer was changed twice during dialysis (Robyt and White, 1987). The dialysat was collected and the enzyme activity was determined.

\section{3- Fractionation of total protein:}

The dialysat was applied to gel filtration column $(2 \times 90 \mathrm{~cm})$ which contains sephadex G-100 (3ml). The elution was carried out using distilled water as eluent and the fractions were collected at flow rate $50 \mathrm{ml} / \mathrm{h}$. The proteinous compounds in each collected fraction (3.5) $\mathrm{ml}$ were detected by following the absorbance at wave length $280 \mathrm{~nm}$ using UV/visible 
spectrophotometer and the assayement of the activity of protease was determined in each fraction.

\section{Determination of the molecular weight by gel filtration:}

The approximate molecular weight was estimated for protease from malignant and benign kidney tumors using sephadex G-100 calibrated with known molecular weight proteins.

The optimum conditions (temperature, time of incubation, $\mathrm{pH}$, concentration of enzyme and substrate) were evaluated and the effect of some inhibitors were studied.

\section{RESULTS AND DISCUSSION}

The results show that the specific activity of protease in malignant kidney tumors is higher than benign and the increment was about (55\%) and this result was in agreement with previous studies which showed a significant increase in protease activity in bladder cancer (Eijan et al., 1997) and in breast cancer (Graratt, 2002). The reason for this increment might be due to both matripase and HAT (Human Airway Trypsine). Expression are recurrently lose their balance resulting in activation of the protease which is correlated with clinical stages (Lee, 2006).

The purification steps of protease from benign and malignant kidney tissues are illustrated in Table $(1,2)$ which indicates that the purification fold of the enzyme is $(47)$ and (54) from benign and malignant respectively.

Table 1: Partial purification of protease from benign tumor tissues

\begin{tabular}{|c|c|c|c|c|c|c|}
\hline Steps & $\begin{array}{c}\text { Volume } \\
\text { (ml) }\end{array}$ & $\begin{array}{c}\text { Total } \\
\text { protein } \\
\text { (mg) }\end{array}$ & $\begin{array}{c}\text { Total } \\
\text { activity } \\
\text { (U)* }\end{array}$ & $\begin{array}{c}\text { Specific } \\
\text { activity } \\
\text { (U/ mg) } * *\end{array}$ & $\begin{array}{c}\text { Purification } \\
\text { folds }\end{array}$ & $\begin{array}{c}\text { Yields } \\
\text { \% }\end{array}$ \\
\hline $\begin{array}{c}\text { Crude } \\
\text { homogenate }\end{array}$ & 45 & 485.76 & 185.3 & 0.38 & 1 & 100 \\
\hline $\begin{array}{c}\text { High speed } \\
\text { supernatant }\end{array}$ & 40 & 236.8 & 162.4 & 0.69 & 2 & 88 \\
\hline $\begin{array}{c}\text { After } \\
\text { precipitation }\end{array}$ & 24 & 110.88 & 140.6 & 1.27 & 3 & 76 \\
\hline Dialysis & 18 & 57.78 & 120.8 & 2.1 & 6 & 65 \\
\hline $\begin{array}{c}\text { Gel filtration } \\
\text { sephadex } \\
\text { (G-100) }\end{array}$ & 39 & 5.85 & 104.6 & 17.88 & 47 & 56 \\
\hline
\end{tabular}

* Enzyme unit: the amount of enzyme used to consume one $\mu$ mole of substrate per minute.

** specific activity of enzyme: number of enzyme units per milligram of protein. 
Table 2: Partial purification of protease from malignant kidney tumor tissues

\begin{tabular}{|c|c|c|c|c|c|c|}
\hline Steps & $\begin{array}{c}\text { Volume } \\
\text { (ml) }\end{array}$ & $\begin{array}{c}\text { Total } \\
\text { protein } \\
\text { (mg) }\end{array}$ & $\begin{array}{c}\text { Total } \\
\text { activity } \\
\text { (U)* }\end{array}$ & $\begin{array}{c}\text { Specific } \\
\text { activity } \\
\text { (U/ mg) } * *\end{array}$ & $\begin{array}{c}\text { Purification } \\
\text { folds }\end{array}$ & $\begin{array}{c}\text { Yields } \\
\%\end{array}$ \\
\hline $\begin{array}{c}\text { Crude } \\
\text { homogenate }\end{array}$ & 50 & 571.5 & 344.6 & 0.6 & 1 & 100 \\
\hline $\begin{array}{c}\text { High speed } \\
\text { supernatant }\end{array}$ & 45 & 294.3 & 310.8 & 1.1 & 2 & 90 \\
\hline $\begin{array}{c}\text { After } \\
\text { precipitation }\end{array}$ & 30 & 164.4 & 284.4 & 1.73 & 3 & 83 \\
\hline Dialysis & 25 & 82.2 & 250.7 & 3.1 & 5 & 73 \\
\hline $\begin{array}{c}\text { Gel filtration } \\
\text { sephadex } \\
\text { (G-100) }\end{array}$ & 36 & 7.2 & 233.7 & 32.46 & 54 & 68 \\
\hline
\end{tabular}

* Enzyme unit: the amount of enzyme used to consume one $\mu$ mole of substrate per minute.

** specific activity of enzyme: number of enzyme units per milligram of protein.

\section{Gel filtration chromatography:}

This technique was used to isolate and purify protease from benign and malignant kidney tissues. The results show that there are three proteineous peaks detected at 280nm. The protease activity was found in the first peak at elution volume of (127) $\mathrm{ml}$ and (131) ml from benign and malignant kidney tissues as shown in (Fig. 1, 2) respectively.

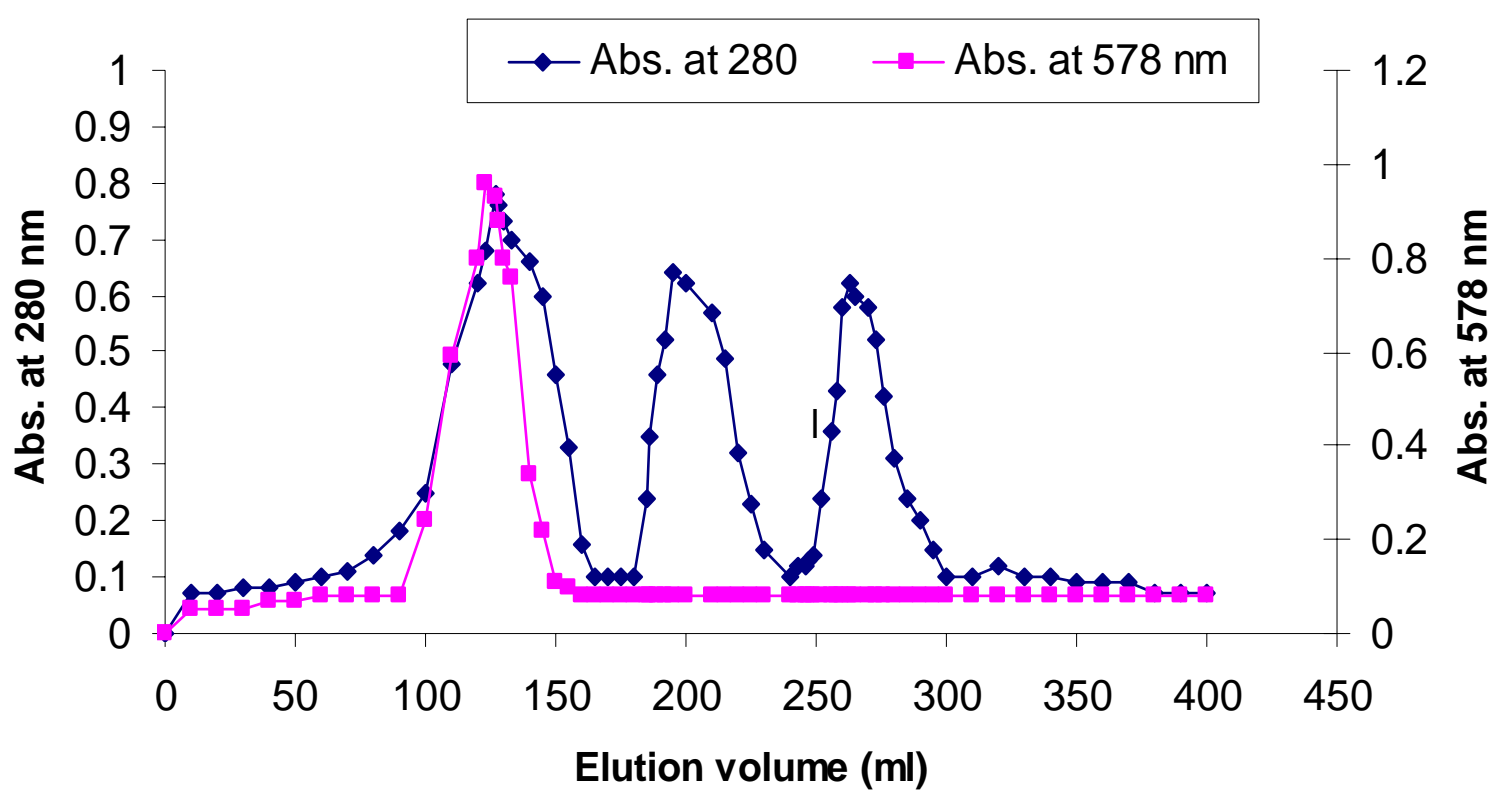

Fig. 1: Partial purification of protease from benign kidney tumor. 


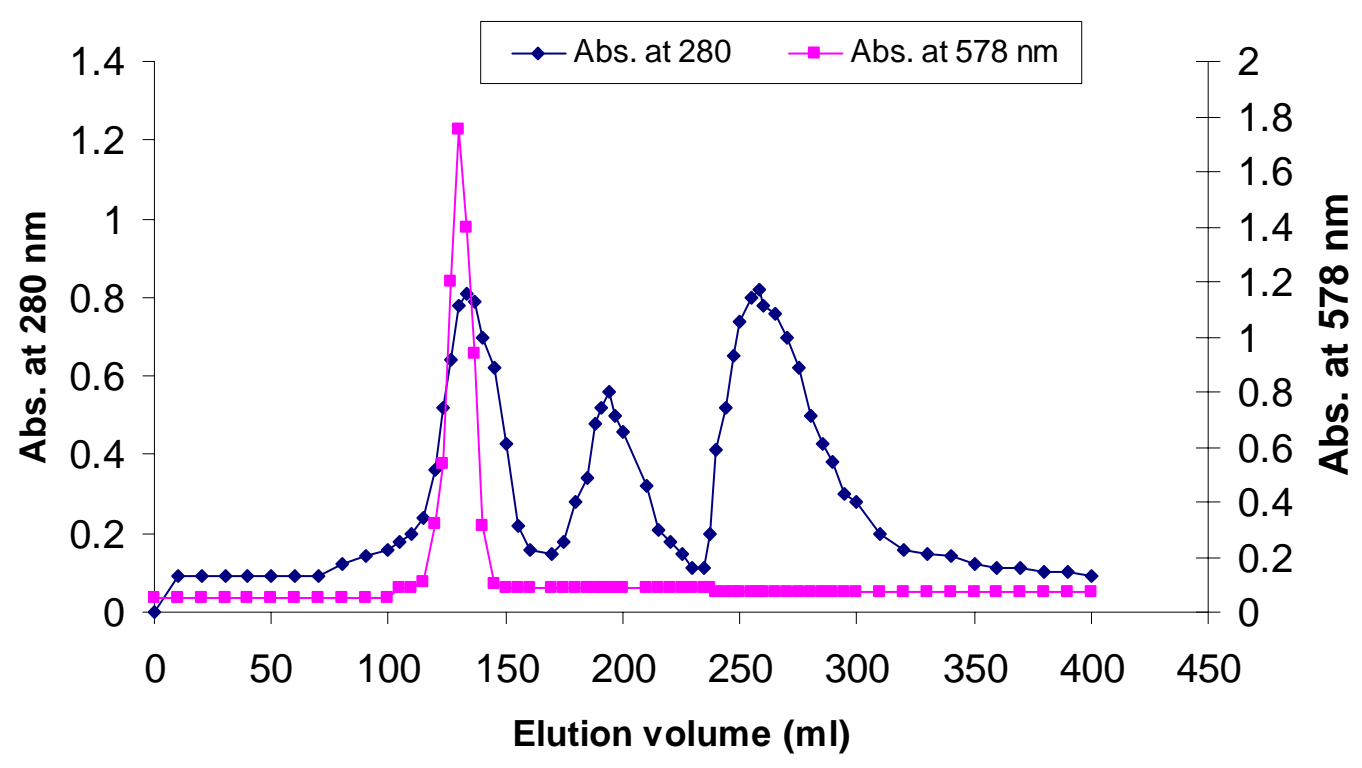

Fig. 2: Partial purification of protease from malignant kidney tumor.

The molecular weight of protease from benign and malignant kidney tissues was estimated, using sephadex G-100 column $(2 \times 90) \mathrm{cm}$ calibrated with known molecular weight proteins Table (3). The plot of logarithmic molecular weight of each material indicated in the table versus their elution volumes gave a straight line, as illustrated in (Fig. $3)$. The results showed that the molecular weight of protease was about (75000 \pm 2000 and $72000 \pm 2000$ ) dalton from benign and malignant kidney tissues and these results were comfortable with other previous study (Sankaralingam et al., 2011) which found that the molecular weight of protease was about (68 KDa).

Table 3: Elution volumes of known molecular weight materials on sephadex G-100

\begin{tabular}{|c|c|c|}
\hline Material & $\begin{array}{c}\text { Accurate Molecular } \\
\text { weight (Dalton) }\end{array}$ & Elution volume (ml) \\
\hline Bluedextran & 20000000 & 80 \\
\hline Glocose oxidase & 186000 & 101 \\
\hline BSA & 67000 & 141 \\
\hline$\alpha$-amylase & 58000 & 167 \\
\hline Papein & 23000 & 242 \\
\hline Tryptophan & 204 & 277 \\
\hline
\end{tabular}




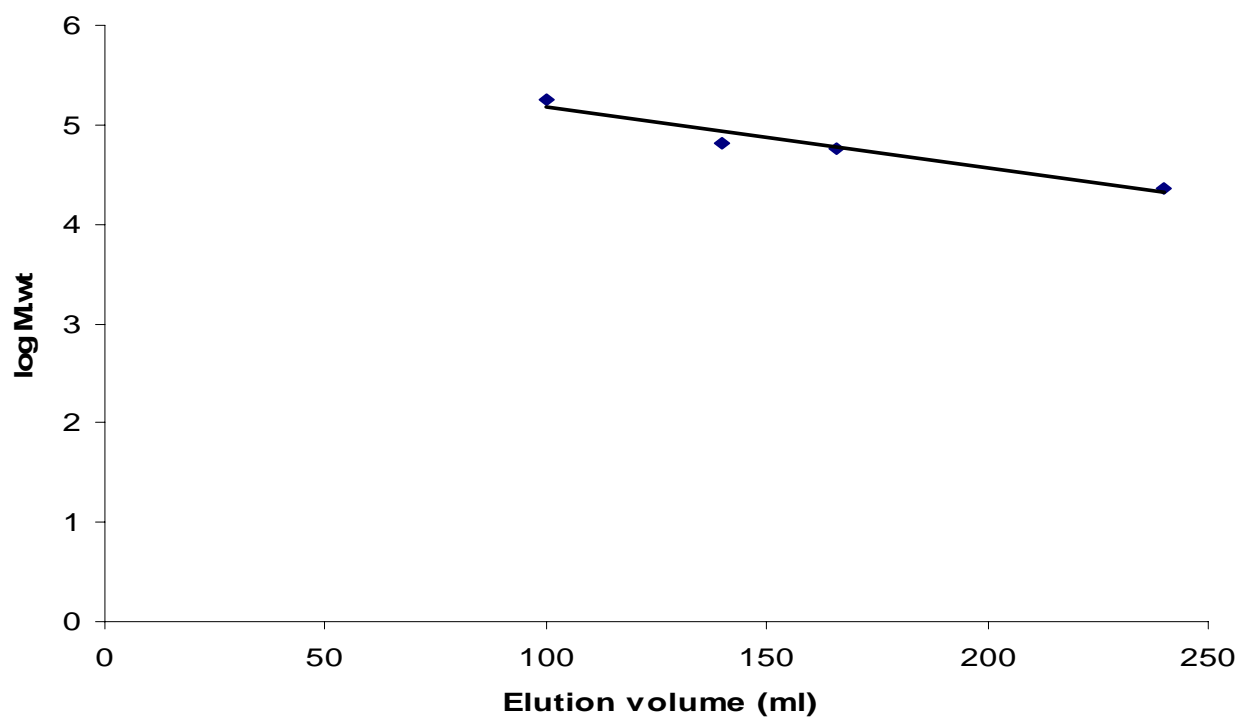

Fig. 3: Plot of the logarithmic molecular weight of known proteins versus elution volume on Sephadex G-100.

\section{Optimum conditions for protease activity:}

The activity of protease in malignant kidney tumor tissues was detected using different concentrations of enzyme, temperatures, $\mathrm{pH}$, times of incubation, substrate concentrations, and accordingly the optimum conditions of the enzyme activity were evaluated.

1- Effect of enzyme concentrations on the enzyme activity:

The activity of protease was measured in the presence of different concentrations of the enzyme and the results showed that the maximum activity of the enzyme was obtained at $8 \mu \mathrm{g} / \mathrm{ml}$ of enzyme concentration as shown in (Fig. 4).

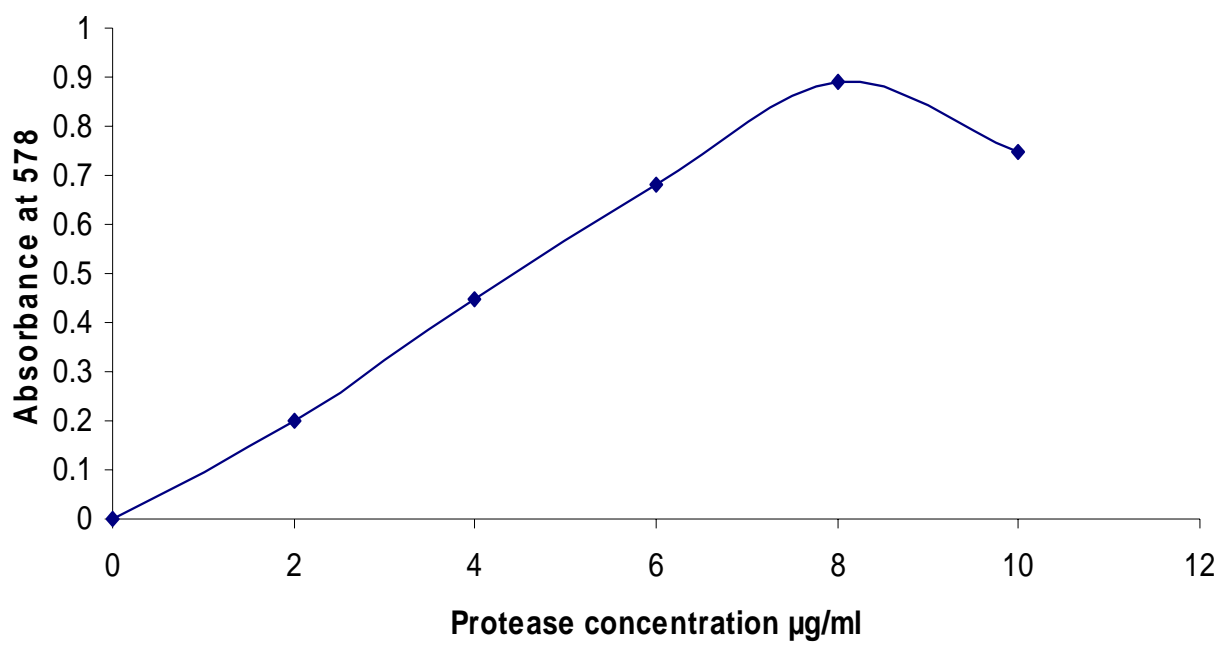

Fig. 4: Effect of enzyme concentration on protease activity 


\section{2- Effect of incubation time on protease activity:}

The activity of the enzyme was measured in different incubation time. The results indicated that the maximum activity was obtained after (1) minute of incubation as shown in (Fig. 5). While the other study indicated that the optimum incubation time was (8) minutes for protease enzyme (Naidu and Lakshmi, 2005).

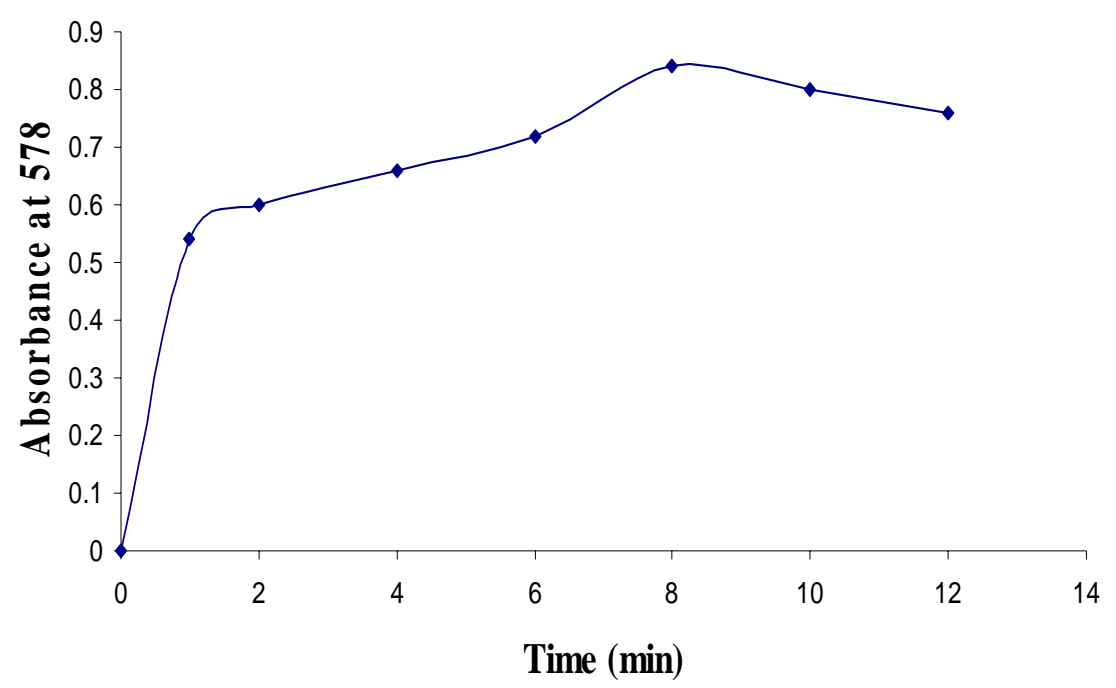

Fig. 5: Effect of time on protease activity

\section{3- Effect of pH on protease activity:}

The effect of $\mathrm{pH}$ on protease activity was investigated at different $\mathrm{pH}$ values (8-10) using sodium borate buffer as shown in (Fig. 6). The results showed that maximum activity of protease was at $\mathrm{pH}(8.8)$ while other studies revealed that the optimum $\mathrm{pH}$ for protease activity was (7) (Sankaralingam et al., 2011), and (9) (Naidu and Lakshmi, 2005).

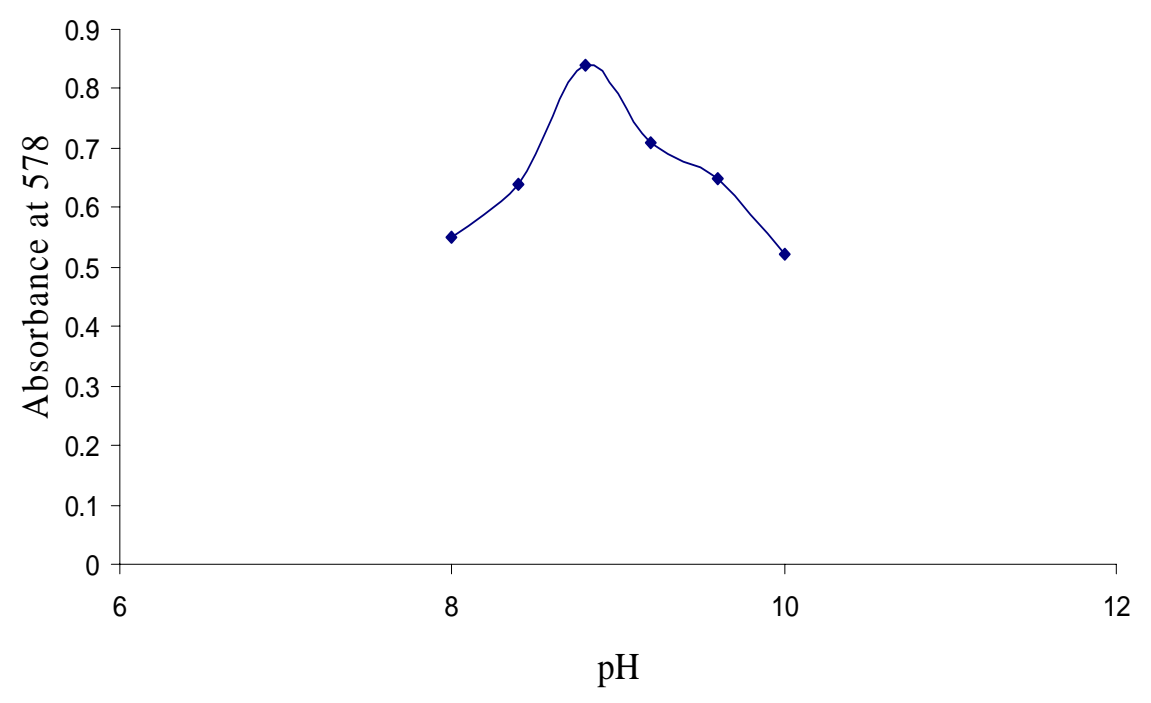

Fig. 6: Effect of $\mathrm{pH}$ on protease activity. 


\section{4- Effect of temperature on protease activity}

The activity of protease was assayed at range of temperature values (10-70) as shown in (Fig. 7). The results indicated that the maximum activity of protease was at $\left(40^{\circ} \mathrm{C}\right)$ and this result was in agreement with Sankaralingam study which found that the optimum temperature for protease activity was $\left(40^{\circ} \mathrm{C}\right)$ (Sankaralingam et al., 2011), while Naidu and Lakshami indicated that the optimum temperature for protease activity was $\left(50^{\circ} \mathrm{C}\right)$ (Naidu and Lakshami, 2005).

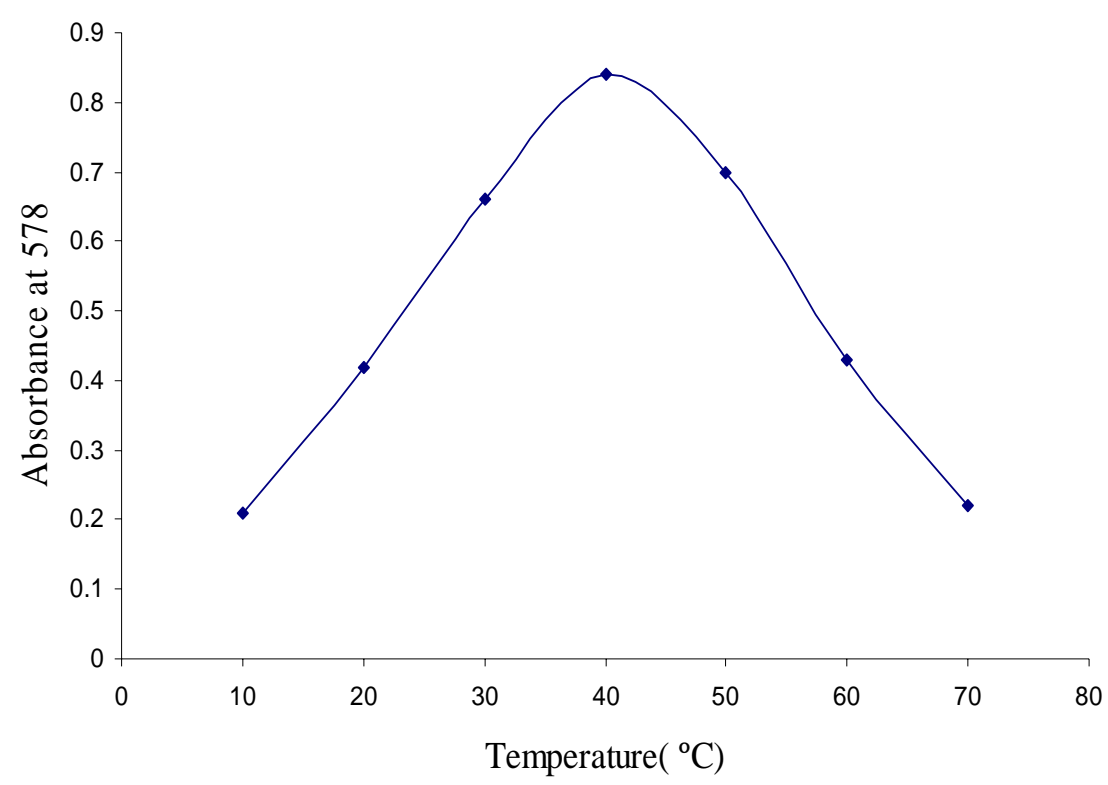

Fig. 7: Effect of temperature on protease activity.

\section{5- Effect of substrate concentration:}

To determine the effect of substrate concentration on protease activity. a series of experiments were performed at different concentrations of casein (0.1-0.8) mmole as a substrate as shown in (Fig. 8).

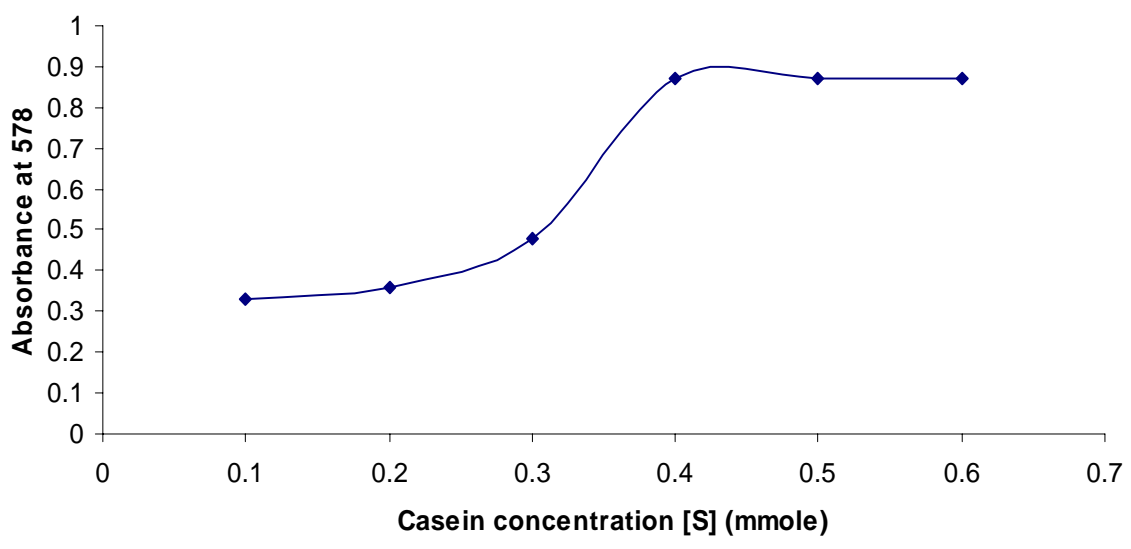

Fig. 8: Effect of substrate concentration on protease activity. 
The activity was increased with increasing the substrate concentration till it reached a limiting value of substrate $(0.4$ mmole). Furthermore, the increase in substrate concentration did not produce any significant change in the activity and follow Michales menten kinetics, using Linweaver-Burk plot as shown in (Fig. 9). The maximum velocity $\mathrm{V}_{\max }$ and Michales Menten constant $\mathrm{K}_{\mathrm{m}}$ were found to be $(0.87) \mathrm{U} / \mathrm{ml}$ and $(0.22) \mathrm{mmole}$ respectively.

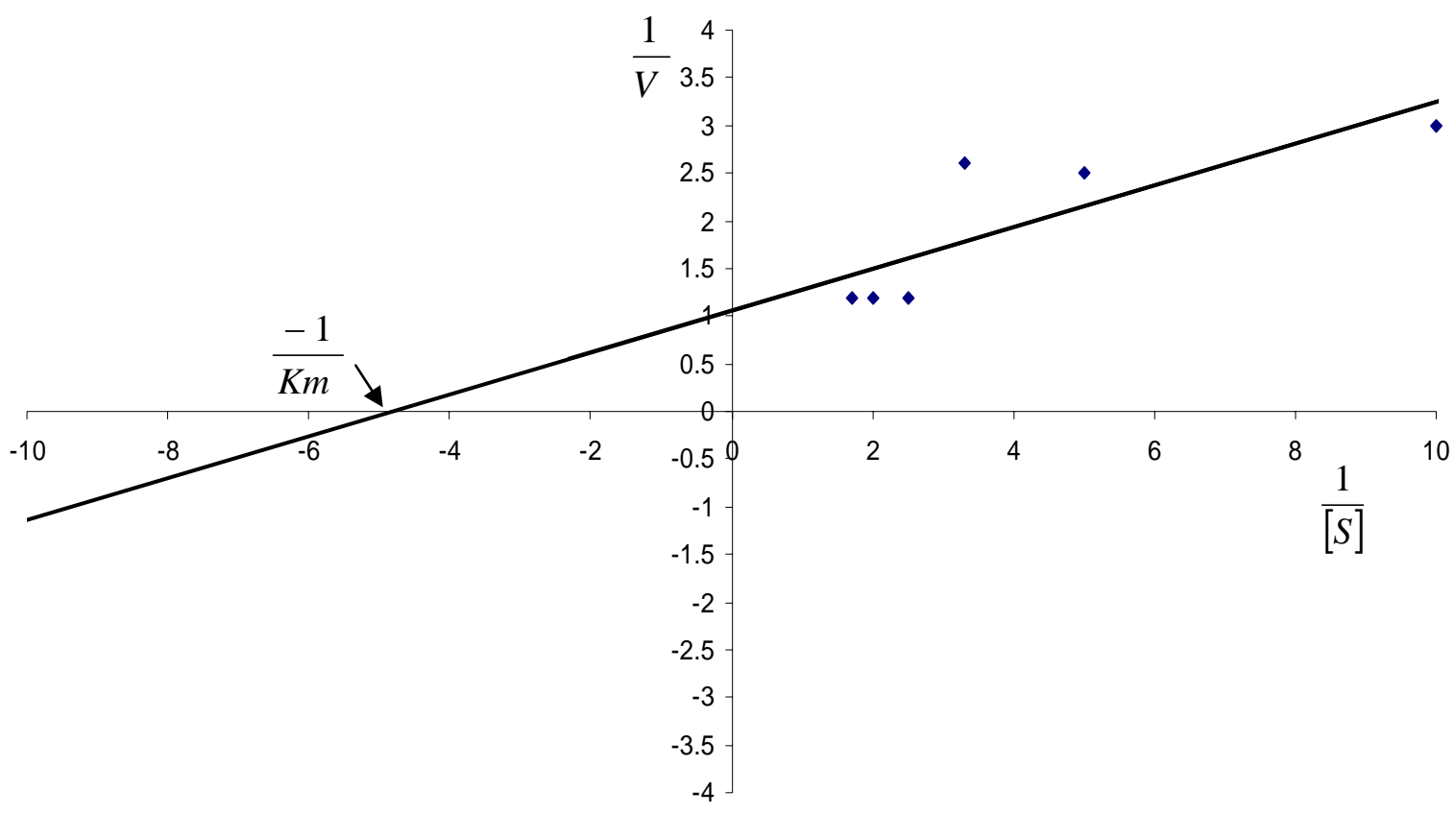

Fig. 9: Linweaver-Burk plot on protease activity.

Table 4: Optimum conditions for protease activity

\begin{tabular}{|c|c|c|c|c|c|c|}
\hline $\begin{array}{c}\text { Substrate } \\
\text { Concentration } \\
\mathbf{m m o l e}\end{array}$ & $\begin{array}{c}\mathbf{V}_{\mathbf{m a x}} \\
\mathbf{U} / \mathbf{m l}\end{array}$ & $\begin{array}{c}\mathbf{K}_{\mathbf{m}} \\
\mathbf{m m o l}\end{array}$ & $\begin{array}{c}\text { Concentration } \\
\text { of enzyme } \\
\mu \mathbf{g} / \mathbf{m l}\end{array}$ & $\mathbf{p H}$ & $\begin{array}{c}\text { Time } \\
\mathbf{m i n}\end{array}$ & $\begin{array}{c}\text { Temperature } \\
{ }^{\circ} \mathbf{C}\end{array}$ \\
\hline 0.4 & 0.87 & 0.22 & 8 & 8.8 & 1 & 40 \\
\hline
\end{tabular}

\section{Effect of some metal ions on protease activity:}

The protease activity was measured in the presence of some chemical compounds like iodo acetamide, mercurous chloride and zinc sulphate which showed an inhibition effect on the protease activity. These metal ions are specifically bind to and chelate with the active side of the enzyme making it inactive in the solution (Qasim and Rani, 2003) while calcium sulphate and magnesium chloride showed an activation effect on the protease activity. 
Table 5: Effect of some chemical compounds on protease activity.

\begin{tabular}{|c|c|c|}
\hline Compound & Protease activity U/ml & Inhibition \% \\
\hline Non & 32.46 & 100 \\
\hline Zinc sulphate & 26.56 & 81.82 \\
\hline Iodoacetamide & 17.54 & 54.03 \\
\hline Mercury(I)chloride & 13.44 & 41.4 \\
\hline Calcium sulphate & 42.62 & 131.3 \\
\hline $\begin{array}{c}\text { Magnesium } \\
\text { chloride }\end{array}$ & 39.68 & 122.2 \\
\hline
\end{tabular}

The percentage of inhibition was calculated with regarding the activity equal $100 \%$ in the absence of these compounds.

\section{REFERENCES}

Eijan, A.; Casabe, A.; Puricel, L.; Pasik, L.; Malagrino, H.; Mato, E.; Toffe, E. (1997). Levels of plasma cystien-protienase activity in bladder cancer patients. Oncology Reports, 4(2), 447-450.

Graratt, B. (2002). Profiling serine protease activities in breast cancer. Scripps Research Institute. www.scripps.edu.

Gupta, R.; Beg, Q.; Lorenz, P. (2002). Bacterial alkaline protease molecular approaches and industrial application. Microbial. Biotechnol., 59, 15-32.

Hooper, N.M. (2002). "Proteases in Biology and Medicine". London, Portland press, 213 p.

Lee, M.S. (2006). Matrix - Degrading type1 trans membrane serine protease matripase and its role in cancer development and malignancy. J. Cancer Molecules, 2(5),183-190.

Naidu, K.; Lakshmi, K. (2005). Optimization of the thermostable alkaline protease production from species of bacillus using rice bran. Biotechnology. 4(7),724-726.

National Cancer Institute (2012). At the national institutes of health www.cancer.gov/cancertropics/types/kidney.

Price, N.C.; Stevens L. (1989). "Fundamental of Enzymology". 2nd ed. Oxford University press, New York, pp. 20-22.

Qasim, K.; Rani, G. (2003). Purification and characterization of an oxidation stable, thiol

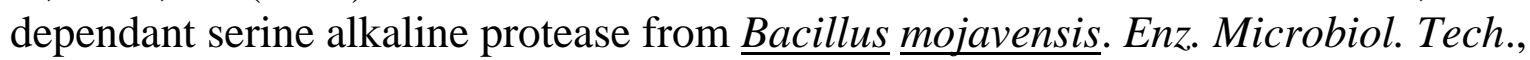
32, 294-304.

Rawlings, N.D.; Barrett, A.J.; Bateman, A.; (2010). MeRops: the peptidase data base. Nucleic Acids Res, 38, D 227-33.

Robyt, J.F.; White, B.T. (1987). "Biochemical Techniques, Theory and Practice". Wads Worth Ine, Belmont, California, U.S.A. 84 p. 
Sankaralingam, S.; Ramasubburayan, R.; Kumar, C.M.; Polaresam, A. (2011). Optimization of culture conditions for the production of an extracellular protease from Shigella sp., Advances in Bioresearch, 2(1), 92-102.

Schacterle, G.R.; Pollack, R.L. (1973). A simplified method for the quantization assay of small amount of protein in biologic material. Anal. Biochem., 51, 654-655.

Sims, G.K. (2006).Nitrogen starvation promotes biodegradation of nitrogenous hetro cyclic compounds is soil. Soil Biology and Biochemistry, 38, 2478-2480.

Worthington Biochemical Corporation (2012). www.worthington-iochem.com/prok/assay/html. 